\title{
Pleuropericardial effusion associated with minoxidil administration
}

\author{
D. B. WEBB \\ M.R.C.P. (U.K.) \\ R. J. WHALE* \\ B.Sc., M.R.C.P. (U.K.) \\ Department of Renal Medicine, K.R.U.F. Institute, Royal Infirmary, Newport Road, Cardiff
}

\begin{abstract}
Summary
A patient on minoxidil developed pericardial and pleural effusions with a high protein content. This finding is not compatible with the view that such effusions in patients taking minoxidil are transudates.

\section{Introduction}

Minoxidil is a powerful vasodilator hypotensive drug which has been used extensively to control blood pressure in patients with renal failure.

Pericardial effusions are associated with minoxidil therapy (Marquez-Julio and Uldall, 1977). In cases where the protein content of the effusion has been examined in patients-some on dialysis-(Martin, Spodick and Zins, 1980; Houston, McChesney and Chatterjee, 1981) it has usually been in excess of $3 \mathrm{~g} / \mathrm{dl}$ although the effusion has often been attributed to the haemodynamic effect of the drug and its tendency to cause fluid retention. The patient reported here developed a pericardial effusion with a high protein content and also pleural effusions. It is suggested that mechanisms other than fluid overload and uraemia may have a role in minoxidil related effusions.
\end{abstract}

\section{Case report}

The patient was a 43-year-old Caucasian male whose hypertension had been noted 2 years previously when he complained of bilateral, intermittent claudication. Treatment with methyldopa, atenolol and frusemide had failed to reduce his supine blood pressure below $240 / 130 \mathrm{mmHg}$ despite compliance with therapy.

Stenosis of the left renal artery was visualized both angiographically and during aortic endarterectomy undertaken to relieve the claudication. It was not possible to correct the renal artery stenosis surgically. Isotope renography carried out when he first presented showed mild impairment of left kidney function. However considerable deterioration in left kidney function was shown on repeat reno-

\footnotetext{
* Reprint requests: Dr R.J. Whale, East Birmingham Hospital, Birmingham B9 5ST.
}

graph after 18 months.

Because of failure to control the blood pressure and the patient's intolerance of hydralazine, minoxidil was commenced at an initial dose of $5 \mathrm{mg}$ twice daily on 6 July, 1980. Creatinine clearance was 35 $\mathrm{ml} / \mathrm{min}$. The minoxidil dose was subsequently increased to $10 \mathrm{mg}$ twice daily with a reduction in supine blood pressure to $200 / 120 \mathrm{mmHg}$. At this time the chest $\mathrm{X}$-ray was within normal limits and retinal examination showed grade II hypertensive retinopathy.

At review on 8 September 1980, the supine blood pressure was $230 / 130 \mathrm{mmHg}$ and the patient was complaining of nocturnal dyspnoea. Examination showed fresh retinal haemorrhages, moderate ankle swelling and fine inspiratory crepitations at the lung bases. The jugular venous pressure was elevated to $8 \mathrm{~cm}$ above the sternal angle and did not vary with respiration. Chest X-ray and echocardiography confirmed a large pericardial effusion and small bilateral pleural effusions. A diagnostic pleural tap was performed and the pericardial sac was also drained of $500 \mathrm{ml}$ of straw coloured fluid. The pericardial source of the fluid was confirmed by insufflation of $5 \mathrm{ml}$ of air.

Both pleural and pericardial effusions had a protein content of $43 \mathrm{~g} / \mathrm{l}$. Neither contained malignant cells nor acid fast bacilli and both were sterile on culture. Antimitochondrial, smooth muscle and antinuclear antibodies were absent in both effusions and serum. The serum DNA binding was found to be within normal limits.

His acetylator status was normal and his HLA group was $\mathbf{A}_{\mathbf{2}} \mathbf{A}_{\mathbf{3}} \mathbf{B}_{\mathbf{8}} \mathbf{B}_{\mathbf{2 7}}$.

The peripheral plasma renin level at the time of minoxidil administration was $5 \mathrm{ng} / \mathrm{ml} / \mathrm{hr}$ (normal range $0 \cdot 2-1 \cdot 0$ ). Despite therapy with frusemide 500 $\mathrm{mg}$ daily the total exchangeable body sodium was $3227 \mathrm{mmol}$ (predicted $2870 \mathrm{mmol}$ ).

Withdrawal of the minoxidil resulted in a rise in the blood pressure and minoxidil was restarted on the basis of reported evidence that pericardial effusions recur in only a few patients following recom- 
mencement of minoxidil. On this occasion recurrence did occur but resolution followed withdrawal of the drug. The blood pressure has subsequently been controlled with captopril $150 \mathrm{mg}$ three times daily, atenolol $200 \mathrm{mg}$ daily, hydralazine $50 \mathrm{mg}$ four times daily and frusemide $500 \mathrm{mg}$ daily.

\section{Discussion}

The occurrence of pericardial effusions in minoxidil-treated patients has been ascribed to the uraemia and the salt and water retention consequent on the vasodilatation produced by this drug. This patient had a minor degree of salt and water retention and the effusions contained $43 \mathrm{~g} / \mathrm{l}$ of protein when the serum albumin was $31 \mathrm{~g} / \mathrm{l}$ and his creatinine clearance $35 \mathrm{ml} / \mathrm{min}$. It is therefore unlikely that the effusions were due to fluid overload alone and the relatively preserved renal function suggests that this patient does not fall into previously published groups. It is perhaps noteworthy that his HLA typing includes B8 and B27 both of which are associated with autoimmune disease although the DNA binding was normal and no antinuclear antibodies were $\frac{3}{3}$ detected.

We do not believe that previous explanations for $\stackrel{\complement}{\complement}$ minoxidil-induced effusions in terms of salt and $\ddot{\vec{\Rightarrow}}$ water retention or renal failure fully account for the $\stackrel{5}{?}$ clinical and laboratory findings in this patient.

\section{Acknowledgment}

We wish to thank Professor A. W. Asscher for permission $\unrhd$ to report this case.

\section{References}

Houston, M.C., MCChesney, J.A. \& Chatterjee, K. (1981) $\overrightarrow{\vec{\omega}}$ Pericardial effusion associated with minoxidil therapy. Archives of Internal Medicine, 141, 69.

Marquez-Julio, A. \& Uldall, P.R. (1977) Pericardial effusions associated with minoxidil. Lancet, ii, 816.

Martin, W.B., SPodick, D.M. \& Zins, G.R. (1980) Peri- i cardial disorders occurring during open-label study of 1869 severely hypertensive patients treated with minoxidil. ปิ Journal of Cardiovascular Pharmacology, 2 (suppl. 2), S217. 